\title{
Effects of artificial disturbance on quantity and biochemical composition of organic matter in sediments of a coastal lagoon
}

\author{
M. Lenzi $i^{(1)}, M$. Renzi(2) \\ Received December 4, 2010 \\ Revised July 6, 2011 \\ Accepted July 9, 2011
}

Key-words: eutrophication, sediment resuspension, lagoon management, organic matter characterization, anoxia

\section{ABSTRACT}

The eutrophication of the coastal lagoon of Burano (Tuscany, Italy) produces periodic toxic-anoxic events. The possibility of mitigating eutrophication of a lagoon by resuspension of sediment was tested in a threeyear field experiment conducted in 2008-2009. An unreplicated beforeafter control-impact (BACl) study design was used to ascertain variations in the quantity and biochemical composition of organic matter in sediment artificially disturbed by a specially equipped boat. In October 2008, before beginning disturbance, January 2009 , half way through the disturbance period, and May 2009, at the end of disturbance, sediment was sampled in a disturbed area and an undisturbed control area to determine chlorophyll-a (Chl-a), phaeopigments (PHAE), proteins (PRT), carbohydrates (CHO), lipids (LIP), labile organic matter (LOM), refractory organic matter (ROM), total organic carbon (TOC) and total nitrogen (TN). The disturbed area, measuring 44 ha, was divided into nine subareas, eight of which were subjected to four different frequencies of disturbance (from 2 to 5) in the period October 2008 - April 2009. Sediment was sampled in each sub-area in the three months mentioned above to determine labile and total organic matter. The results were processed by univariate and multivariate analysis using Primer 6.0, Permanova + and Prism 5.0 software. The findings were as follows: (1) a large proportion of the biopolymeric carbon consisted of labile matter throughout the lagoon; (2) higher abatement of labile organic matter was recorded in the disturbed area; (3) a lower protein:carbohydrate ratio was found in the disturbed than in the undisturbed area; (4) the C:N ratio of sediment was much lower in the undisturbed area than in the disturbed area at the end of the study period; (5) sediment and macroalgal C:N ratios did not significantly change in response to disturbance; (6) initial accumulation of organic matter from phytoplankton was greater in the disturbed area than the undisturbed area; (7) chlorophyll-a, phaeopigments and the pigment diversity index did not reflect any decline in photosynthesis in the disturbed area; (8) treatment effects increased with increasing frequency of disturbance. These findings indicate less availability of labile organic matter and therefore lower risk of extended anoxic events in the disturbed area and support our hypothesis that artificial disturbance of sediment can be used to manage lagoon environments and prevent the consequences of eutrophication. 


\section{RÉSUMÉ}

Les effets de perturbations artificielles sur la quantité et la composition biochimique des matières organiques des sédiments d'une lagune côtière

Mots-clés:
eutrophisation,
remise en
suspension
des sédiments,
gestion,
lagune,
matières
organiques,
anoxie

L'eutrophisation des lagunes côtières de Burano (Italie) produit périodiquement des événements toxiques-anoxiques. Atténuer l'eutrophisation par remise en suspension des sédiments a été testé dans des expériences de terrain (2008-2009). Un protocole de type $\mathrm{BACl}$ a été utilisé pour vérifier les variations dans la composition biochimique de la matière organique dans les sédiments perturbés par un bateau spécial. Les sédiments ont été prélevés avant, pendant et après la perturbation, dans une zone perturbée (D) et une zone non perturbée (UD) pour déterminer : chlorophylle a, phéopigments, protéines, glucides, lipides, matière organique labile (LOM), matière organique réfractaire, carbone organique total et azote total. D (44 ha) a été divisé en neuf sous-zones qui ont été soumises à des fréquences différentes de perturbations (2 à 5). Les sédiments ont été prélevés pour déterminer la LOM et le total des matières organiques (MO). Les résultats ont été traités par analyse univariée et multivariée. Les résultats sont les suivants : (1) une forte proportion de carbone biopolymère composé de LOM dans le lagon; (2) une réduction plus importante en LOM a été enregistrée en D; (3) un plus faible rapport protéines:glucides en D que dans UD; (4) un rapport C:N des sédiments devenu beaucoup plus faible dans UD que dans D; (5) le rapport C:N des sédiments et des macro-algues n'a pas sensiblement changé en réponse aux perturbations; (6) l'accumulation initiale du phytoplancton $\mathrm{OM}$ a été plus grande dans D que UD; (7) chlorophylle-a, phéopigments, et indice de diversité pigmentaire ne reflètent aucune diminution de la photosynthèse dans $D$; (8) les effets du traitement augmentent avec la fréquence des perturbations. Ces résultats indiquent une plus faible disponibilité de LOM et donc un risque moins fort d'événements anoxiques dans $D$ et confirment notre hypothèse que la perturbation artificielle des sédiments peut être utilisée pour prévenir les conséquences de l'eutrophisation.

\section{INTRODUCTION}

Eutrophication in lakes and coastal environments leads to accumulation of organic carbon in sediment (Cornwell et al., 1996; Farias, 2003). In marine sediments, including those of lagoons and other transitional environments, more than $50 \%$ of organic matter is degraded by bacterial sulphate-reduction (Jørgensen, 1983). As many coastal lagoons and estuaries become eutrophic due to high nutrient load and accumulation of organic matter (Morand and Briand, 1996), the anoxia established in sediments and $\mathrm{H}_{2} \mathrm{~S}$ release lead to increasing degradation and continual stress for populations in the warm season, resulting in selection of opportunistic species and sudden drastic changes in the phytobenthos (Valiela et al., 1997). Major build up of organic matter in sediments increases sulphate-reduction, producing the acidifying gases $\mathrm{CO}_{2}$ and $\mathrm{H}_{2} \mathrm{~S}$; the latter is toxic and may have considerable impact (Heijs et al., 2000). The sediment becomes more acidic and reaches low redox values, leading to build-up of reducing chemical components. In these conditions, rooted-plant development is curbed by bacteria, chemical agents, epiphytes, phytoplankton and floating macroalgae (Den Hartog, 1994; Raffaelli et al., 1998). Eutrophication favours a transition from seagrasses to seaweeds and opportunistic microphytes (Duarte, 1995). Lenzi et al. (2003) observed a macroalgal distribution gradient with phosphorophilic macroalgae near an anthropogenic nutrient source, and nitrophilic macroalgae at some distance from it, in a phosphorus-limited lagoon environment.

In shallow eutrophic lagoons, occasional resuspension of soft sediment, for example by strong winds, can have a considerable impact on the water body (Hopkinson, 1985), releasing 
nutrients as well as reducing, acid and toxic compounds, which can further favour the growth of opportunistic vegetation, give rise to sudden anoxic events and cause stress for flora and fauna communities (Wainright and Hopkinson, 1997). Though there have been contradictory results and different opinions about the effects of resuspension of sediment on the water column, it is broadly accepted that these results depend on the nature of the sediments, the quality of organic matter and the environmental conditions under which disturbance occurs (Arnosti and Holmer, 2003; Tengberg et al., 2003).

Nevertheless, in the framework of such eutrophic environments with low water renewal, frequent disturbance of sediment produces clearer results than occasional disturbance. Indeed, frequent sediment resuspension has physical and geochemical effects on the sediment, such as changes in sediment texture, redox increase and oxidation of iron to ferric oxides (Golterman, 2001), as well as biological effects, such as an increase in oxydative mineralising strains of prokaryotes, leading to increased mineralization rate (Wainright, 1990), that can also involve neighbouring areas, following transport of resuspended matter (Logan and Kirchman, 1991). The end result is a decrease in sediment organic matter (Stahlberg et al., 2006; Lenzi et al., 2005, 2010). The ferric oxides-hydroxides bind orthophosphates (Golterman, 2001), that become depleted in interstitial water and above all in the water column, causing P-limitation, which is followed by a decrease in macroalgal development and a change in macroalgal quality (Lenzi et al., 2003). The drop in competition from opportunistic macroalgae favours seagrasses (Lenzi et al., 2010), which absorb nutrients directly through their roots. Hence resuspension of sediment may be used to remediate eutrophication and anoxic events in lagoons (Lenzi, 2010).

Lenzi et al. $(2005,2010)$ conducted experiments to clarify the effects of resuspension on the water column, sediment and vegetation, with a view to using resuspension as a method to counteract the effects of eutrophication. These experiments did not show any negative effects of resuspension on physical and chemical parameters of the water column over a relatively long period of disturbance, and they showed a decrease in sediment organic load, variations in sediment density and porosity, a drastic reduction in macroalgal development and an increase in seagrass (with many seedlings establishing directly from seed). The trend of dissolved sulphides also suggested that disturbance interrupted sulphate reduction processes.

During a three-year experimental programme aimed at evaluating the possibility of mitigation of eutrophication by sediment resuspension in the small coastal lagoon of Burano, prompted by the first encouraging analytical results and changes in environmental quality (Lenzi et al., 2010), it was observed that organic load responded progressively less to disturbance in time. This suggested that the sediments were becoming enriched in refractory organic matter (more resistant to oxydative mineralization and less biodegradable), in line with results obtained in other environments by Pusceddu et al. (2005). In fact, the quality of organic matter in sediments may be a more informative index of the trophic status of marine environments than the quantity of organic matter (Fabiano et al., 1995; Cebrián et al., 1998). Sediment concentrations of major biochemical components (i.e. proteins, carbohydrates and lipids) vary with ecosystem productivity and trophic status, and trophic changes are evident as changes in the composition of organic matter (OM) (e.g. protein:carbohydrate ratio) more than in OM concentration (Fabiano et al., 1995; Danovaro et al., 1999). Thus the biodegradable fraction of OM may influence benthic metabolic processes (Danovaro et al., 1999).

In the present study, we therefore also considered changes in quality in response to resuspension. In the framework of our research into the effects of resuspension on lagoon environments and the possibility of using resuspension as a method for managing environmental quality, the two main aims of the present study were: (1) to characterize sedimentary organic matter, evaluating variations in quality (labile-refractory, carbohydrates, proteins, lipids and other components) in response to prolonged resuspension, and (2) to determine a frequency of disturbance sufficient to reduce the risk of dystrophy by reducing bioavailable organic matter. 

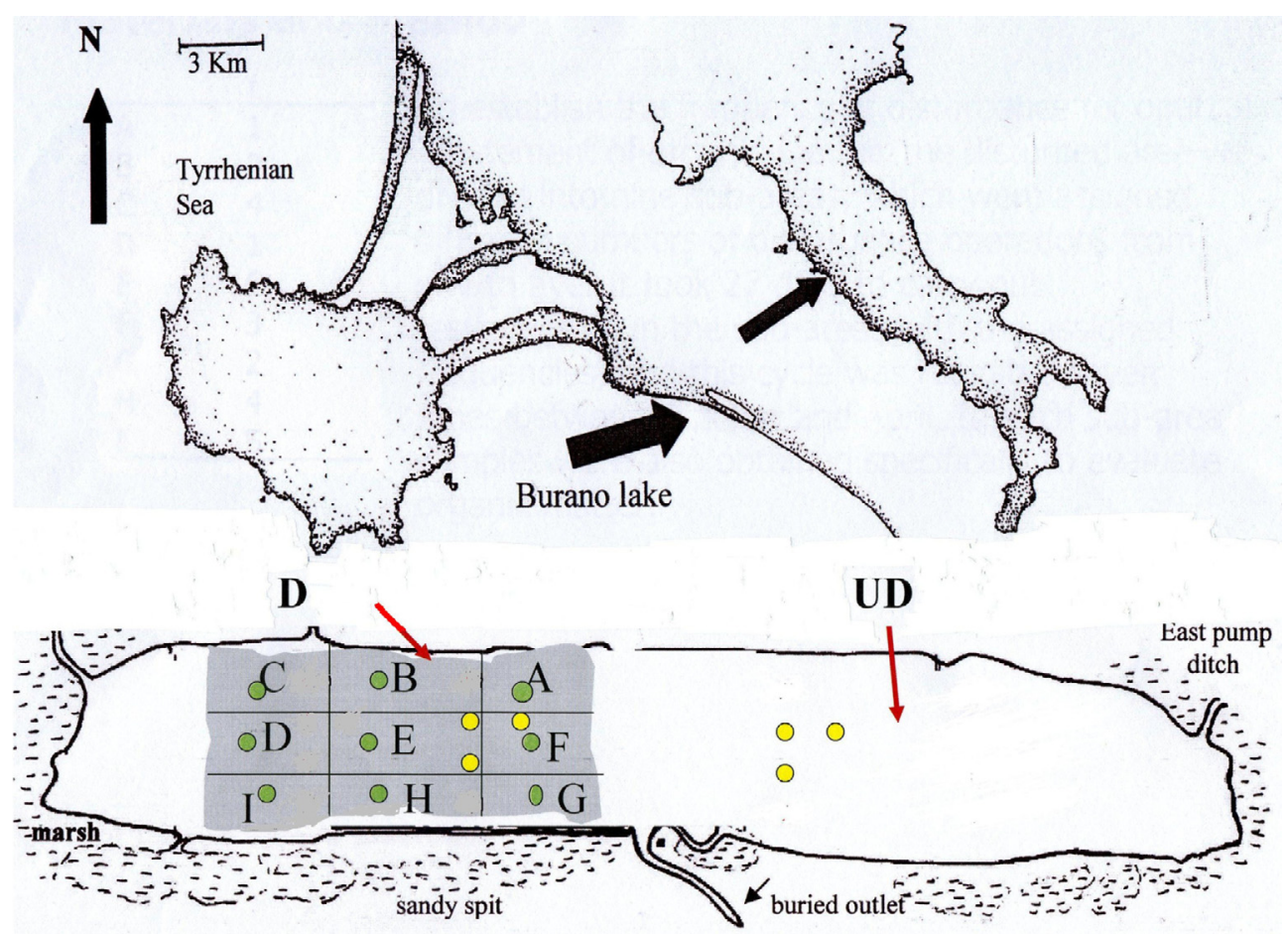

\section{Figure 1}

The coastal lagoon of Burano. In grey, the disturbed area (D), situated in the western part of the lagoon; in white, the undisturbed or control area (UD) in the eastern part. A-I subareas in which disturbance was conducted with different frequencies $(n): B, I=2 ; C, F=3 ; H, A=4 ; E, G=5$. Green dots are sampling stations for studying disturbance frequency effects-experimental plan. Yellow dots are sampling stations for sediment organic matter characterization-experimental plan in D and UD.

\section{Figure 1}

La lagune côtière de Burano. En gris, la zone perturbée (D), située dans la partie ouest de la lagune; en blanc, la zone non perturbée ou de contrôle (UD) dans la partie orientale. A-I sous-zones dans lesquelles la perturbation a été menée avec des fréquences différentes $(n): B, I=2, C, F=3, H, A=4, E, G=5$. Les points verts sont les stations de prélèvement pour l'étude de la fréquence des perturbations sur les effets expérimentaux. Les points jaunes sont des stations de prélèvement pour la caractérisation expérimentale de la matière organique des sédiments dans $\mathrm{D}$ et UD.

\section{MATERIAL AND METHODS}

\section{> STUDY AREA}

The coastal lagoon of Burano (Tuscany, Italy; Figure 1) is a non-tidal environment, separated from the sea by a sandbar. Its area is 120 ha with a mean depth of about $0.8 \mathrm{~m}$. The lagoon stretches along the coast in a NW-SE direction. In the period 2006 to 2009, salinity ranged from 5 to $27 \mathrm{PSU}$, depending on rain, evaporation and phreatic seawater supply, with a temperature range of $9-28{ }^{\circ} \mathrm{C}$. $\mathrm{pH}$, dissolved oxygen and acid volatile sulphide were 7.1-9.4, $32-190 \%$ and $0-6.1 \mu \mathrm{M}$, respectively, largely dependent on temperature and photosynthesisrespiration.

The lagoon receives rainwater from an agricultural catchment, measuring about $13.7 \mathrm{~km}^{2}$, created more than a century ago by wetland reclamation. The two main channels convey nutrient-rich agricultural run-off and treated wastewater from a village. External inputs of organic solids are minor and sporadic, due to the length of the network of input channels, in which they tend to be deposited before entering the lagoon (WWF-Italia, 1993). The lagoon is characterized by alternating periods of seagrass development, dominated by Ruppia cirrhosa (Petagna) Grande, to densities of about $3 \mathrm{~kg}_{\mathrm{ww}} \mathrm{m}^{-2}$, and blooms of opportunistic macroalgae, 
dominated by the macro-chlorophycea Chaetomorpha linum (O.F. Müller) Kützing, at densities up to $20 \mathrm{~kg}_{\mathrm{ww}} \mathrm{m}^{-2}$ (WWF-Italia, 1993).

To prevent flooding of the surrounding land during periods of heavy rain, an outlet to the sea is opened by an excavator in a sandy dune. This is typically necessary $3-5$ times per year.

Burano lagoon was chosen for the following reasons: (1) it is relatively small which means that effects are not masked by those of extended areas of water; (2) it is elongated in form and relatively sheltered from the wind; (3) its sediment has never been disturbed by humans since land reclamation in the early 1900s; (4) there are no major external inputs of organic matter from outside, hence decomposition is largely from autochthonous primary producers mass (WWF-Italia, 1993).

Annual organic detritus comes largely from decay of macroalgae, since seagrass fronds are more resistant to decay. Macroalgal decomposition occurs largely in the second half of summer and the detritus is available mostly in autumn. This is why sediment disturbance operations were undertaken starting in October, when detritus, presumably rich in the bioavailable fraction of organic matter, is at a maximum. At this time of year, mineralization may be rapid, depending on temperature and oxygen dissolved in the water column, but not particularly critical for the lagoon environment. On the contrary, when macroalgal production is abundant, summer macroalgal decomposition may give rise to a toxic-anoxic event. In a previous experience (Lenzi et al., 2010) in the same lagoon, we studied the dynamics of OM accumulation over the period of a year. However, in the present study we excluded the hottest months, because we consider that treatment of sediment and evaluation of the effects should be carried out before a critical stage is reached.

\section{> EXPERIMENTAL DESIGN}

The experimental design was concerned with two aspects: (i) the general effects of mechanical disturbance on chemical characteristics of sedimentary organic matter; (ii) the effect of the frequency of treatments. An unreplicated (one lagoon) before-after control-impact (BACl) design was used in both cases to detect, on a statistical basis, changes in means associated with sediment disturbance. Sediment was disturbed mechanically causing resuspension of approximately the top $3 \mathrm{~cm}$ of sediment. This effect was carried out by a boat especially designed to produce jets of water and air directed towards the bottom. Two $0.75 \mathrm{Kw}$ motors were mounted on steel frames on either side of the hull so that the shafts could be inclined at different angles in relation to vessel speed and water depth. The equipment is described in Lenzi et al. (2010). Disturbance of sediment was concentrated in the western sector of the lagoon in an area measuring 44 hectares, defined "disturbed area" (D) (Figure 1), and it was carried out in the period October 2008 to April 2009.

In this study we only considered sediment and not the water column. In a previous study, the water column proved to be relatively unaffected by prolonged disturbance of sediment and to have very homogeneous physicochemical characteristics (Lenzi et al., 2010).

\section{Effect of resuspension of sediment}

Sampling was organized in two experimental plans. The first, that we named "organic matter characterization" was designed to evaluate any quantitative differences in variables between $\mathrm{D}$ and the undisturbed area (UD; Figure 1). The second plan, named "frequency effects", was designed to evaluate relationships between variables and frequency of disturbance; it was only focused on the disturbed area and variables significantly affected by disturbance identified in the first plan, selecting those that best lent themselves to monitoring for lagoon management.

\section{Organic matter characterization - experimental plan}

For the first experimental plan, sampling was based on three factors: disturbance (two levels, fixed: $\mathrm{D}$ and UD), disturbance time (three levels, fixed: $\mathrm{T}_{0}$ - before starting disturbance 
(October 2008), $T_{1}$ - midway through the disturbance period (January 2009), $T_{2}$ - at the end of the disturbance period (May 2009); two levels for total organic carbon (TOC) and total nitrogen (TN): $T_{0}, T_{2}$ ) and replicates (three levels, randomly in each stratum to reduce sampling error according to Cochran, 1977), collecting $n=18$ records. Stratified sampling design was used (Benedetti-Cecchi, 2004), first dividing the system into homogeneous strata on the basis of physico-chemical sediment descriptors. Pairs of sampling stations were matched for sediment characteristics, and chosen as far apart as possible to exclude crossed spatial interference. Specifically, D and UD stations (Figure 1) were located on the basis of previous determinations (Lenzi et al., 2010), choosing two areas that were relatively homogeneous in terms of bulk density (D, $1.22 \pm 0.06 \mathrm{~g} \cdot \mathrm{cm}^{-3}$; UD, $\left.1.20 \pm 0.04 \mathrm{~g} \cdot \mathrm{cm}^{-3}\right)$, porosity $(\mathrm{D}, 0.83 \pm$ 0.01 ; UD, $0.84 \pm 0.03$ ) and grain-size (i.e. fraction < $63 \mu \mathrm{m}$ : D, $89.12 \pm 1.18 \%$; UD, $87.99 \pm$ $3.05 \%)$. Standard deviations within \pm 0.1 for density $\left(\mathrm{g} \cdot \mathrm{cm}^{-3}\right)$ and porosity and within $\pm 3 \%$ for the under-63- $\mu \mathrm{m}$ fraction were considered to indicate homogeneity among strata.

At each sampling station, samples of the macro-alga $C$. linum were collected in three replicates at $T_{0}$ and $T_{2}$ to determine levels of TOC and TN; the aim was to evaluate relationships between sediment organic matter and tissue content in dominant species of macroalgae.

\section{Effects of intervention frequency - experimental plan}

In the second experimental plan, the disturbed area of $44 \mathrm{~h}(\mathrm{D})$ was divided into nine subareas (named A to I; Figure 1), eight of which were assigned different frequencies of disturbance from two to five (in pairs, with the exception of subareaD, unreplicated frequency of one, not further considered in the statistical analysis). It took 27 days to carry out resuspension with the assigned frequencies in all subareas, and this cycle was repeated seven times between October and April. Overall, the subareas were disturbed 7 to 35 times in 7 months. In each subarea, a station was established (Figure 1), where three samples were collected to evaluate labile organic matter (LOM), refractory organic matter (ROM) and OM at $\mathrm{T}$ (October), $\mathrm{T}_{1}$ (January) and $\mathrm{T}_{2}$ (May). Sampling was performed according to a model based on fixed and random factors, as suggested by Underwood $(1992,1993)$ and Benedetti-Cecchi (2004). A four-factor design based on disturbance frequency (four levels, fixed: from 2 to 5), disturbance replicates (two levels, random), disturbance time (three levels, fixed: $T_{0}, T_{1}, T_{2}$ ) and sampling replicates (three levels, random) was used, collecting a total of 72 records.

\section{> SEDIMENT SAMPLING AND ANALYTICAL CHARACTERIZATION OF ORGANIC MATTER}

Proteins, carbohydrates (except structural polysaccharides) and lipids are the fraction of organic carbon most reactive to degradation and available to heterotrophic microbes and organisms at higher trophic levels (Pusceddu et al., 2003). This fraction, defined as organic biopolymeric carbon (BPC; Fabiano et al., 1995), constitutes $10-70 \%$ of the total organic carbon pool in sediments.

On the other hand, refractory organic matter (also known as complex organic matter) consists of complex macromolecules (humic and fulvic acids and structural carbohydrates such as cellulose and chitin). Since this component is more resistant to microbial breakdown, it tends to be buried and accumulate in sub-surface layers of sediment, where it only becomes available to consumers after long periods of intense microbial activity (Middelburg et al., 1999). Thus, the different origin and stage of decomposition of organic matter in sediments affect its rates of decomposition and its utilization by benthic heterotrophic microbes (Tenore et al., 1982).

In this study, we sampled sediment in the upper $3 \mathrm{~cm}$ using a horizontal sampler with $60 \mathrm{~mL}$ syringe, lowered from the boat and guided by an appropriate device (Figure 2). The variables measured were: chlorophyll-a (Chl-a), phaeopigments (PHAE), proteins (PRT), carbohydrates $(\mathrm{CHO})$, lipids (LIP), total organic matter (OM), LOM, TOC and TN.

No other variable was determined, since bulk density (range $1.43-0.75 \mathrm{~g} \mathrm{~cm}^{-3}$ ), porosity (range 0.99-0.50) and grain size (fraction $<63 \mu \mathrm{m}$, range 50-95\%) had previously been 


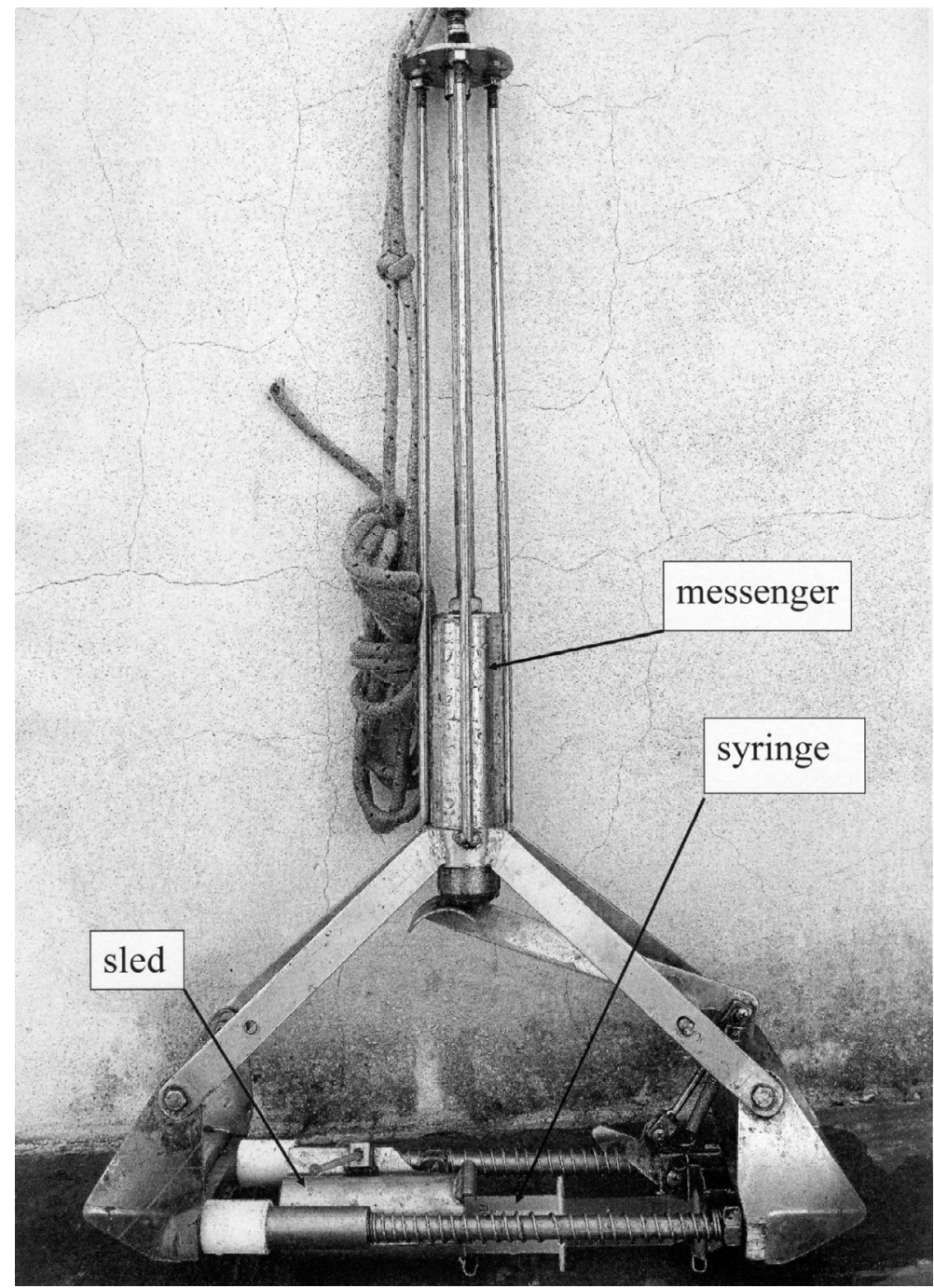

\section{Figure 2}

Device for horizontal sampling of the top few centimeters of sediment. The instrument is lowered into the sediment. The messenger is activated from the boat and triggers the spring which moves the sled carrying the syringe, which fills with sediment.

\section{Figure 2}

Dispositif pour l'échantillonnage horizontal de quelques centimètres de sédiments. L'instrument est descendu dans les sédiments. Le messager est activé à partir du bateau et déclenche le ressort qui déplace le traîneau portant la seringue, qui se remplit de sédiments.

determined in 120 stations (one per hectare) in order to characterize the whole lagoon (Lenzi et al., 2010).

All samples for LOM, ROM and OM determinations from the two experimental plans stations were dried at $90^{\circ} \mathrm{C}$. LOM, ROM and OM were determined as loss of weight after combustion for $3 \mathrm{~h}$ at $250{ }^{\circ} \mathrm{C}, 400{ }^{\circ} \mathrm{C}$ and the sum of the two, respectively. Heating temperature and exposure time were chosen from the literature (Di Nigel, 2002; Loh, 2005; Wang and Li, 2010) and our previous experience on sediment sources. The labile organic components determined by this method are not the same as BPC, which includes all carbohydrates and could contain a preponderance of refractory structural carbohydrates.

All other samples from organic matter characterization-experimental plan- stations were weight-normalized after drying at $60{ }^{\circ} \mathrm{C}$. Determinations of $\mathrm{Chl}$-a and PHAE were conducted 
according to Lorentzen and Jeffrey (1980) Total phaeopigment concentrations (T-PIG) were obtained as the sum of the concentrations of Chl-a and PHAE (Dell'Anno et al., 2002). The proportion of Chl-a with respect to total phaeopigment content was calculated as a percentage (PDI). PRT was determined by the colorimetric method of Hartree (1972) and expressed as bovine serum albumin equivalent. CHO was determined according to Dubois et al. (1956), optimized for sediments by Gerchakov and Hatcher (1972). The absorbance of samples was converted to concentration using a calibration curve obtained with standard solutions of $\mathrm{D}(+)$ glucose. LIP was determined by the spectrophotometric method of Marsh and Wenstein (1966) after extraction with methanol and chloroform (1:1 v/v) according to Bligh and Dyer (1959) and expressed in tripalmitine equivalents.

The correction factors in PRT, CHO and LIP were determined as the mean of the ratios of sediment dry weight (5 replicates) before and after the analysis treatments (Pusceddu et al., 2003).

BPC was computed as the sum of carbon equivalents of CHO, PRT and LIP according to Fabiano et al. (1995). The protein:carbohydrate ratio (PRT:CHO) was calculated.

TOC and TN were determined using a CHN ThermoFinnigan model EA 1110. The C:N atomic ratio was also calculated.

\section{> STATISTICAL ANALYSIS}

To improve the homogeneity of variance, the dataset was square root- $(\sqrt{ })$ and $\log (x+1)$ transformed, and normalized prior to statistical analysis. Univariate analysis was performed using GraphPad Prism software version 5.00 for Windows (GraphPad Software, San Diego California USA, www.graphpad.com). Average, maximum, minimum and standard deviation of variables were calculated. With regard to univariate analysis, the D'Agostino and Pearson omnibus normality test was calculated to evaluate the best correlation matrix for each dataset. Coupled correlations were then determined and regular two-way ANOVA was performed.

Multivariate analysis was conducted using Primer-E version 6.0 (Plymouth Marine Laboratory, UK), according to methods proposed by Clarke and Warwick (2001). Euclidean distance resemblance matrices were calculated on pre-transformed and normalized data, and Principal Components Analysis (PCA) was applied to the matrices to investigate correlations and similarities between environmental variables.

Distance-based redundancy analysis (dbRDA) was carried out using a three-step process: first, a distance matrix was calculated using the distance measure of choice. Next, the matrix was subjected to principle coordinates analysis (PCoA). Finally, the eigenvalues obtained by $\mathrm{PCoA}$ were plugged into an RDA. The total variation accounted for by each axis was also reported.

The significance of the ordinations related to the different factors was tested by one-way and two-way ANOSIM statistic R, running 9.999 permutations. This procedure tests hypotheses for differences between groups of samples (according to a factor defined a priori), using permutation/randomisation methods on a resemblance matrix as reported in the literature (Benedetti-Cecchi, 2004). The ANOSIM test was run imposing a pairwise routine to evaluate the significance of pairs of factors.

\section{RESULTS}

\section{> EFFECT OF RESUSPENSION ON ORGANIC MATTER CHARACTERISTICS - EXPERIMENTAL PLAN}

The effects of resuspension of sediment on mean sediment descriptors are reported in Table I. Chl-a was higher on the whole in $D\left(6.7 \pm 3.7 \mu \mathrm{g} \cdot \mathrm{g}^{-1}\right)$ than in UD $\left(3.9 \pm 1.0 \mu \mathrm{g} \cdot \mathrm{g}^{-1}\right)$; in $\mathrm{D}$, it increased between $T$ and $T_{1}$ and decreased between $T_{1}$ and $T_{2}$; on the contrary, in UD, it 


\section{Table I}

Effects induced by resuspension of sediment. Mean \pm standard deviation of sediment descriptors. The data is grouped according to the factors disturbance (two levels, fixed: $D$ and UD) and disturbance time (three levels fixed: $T_{0}, T_{1}, T_{2}$ ). OM = total organic matter (\%), LOM = labile organic matter (\%), TOC = total organic carbon (\%), TN = total nitrogen (\%), Chl-a = Chlorophyll-a $\left(\mu g \cdot g^{-1}\right)$, PHAE = phaeopigments $\left(\mu g \cdot g^{-1}\right), P R T=$ proteins $\left(m g \cdot g^{-1}\right), C H O=$ carbohydrates $\left(m g \cdot g^{-1}\right), L I P=$ lipids $\left(m g \cdot g^{-1}\right), B P C=$ biopolymeric carbon $\left(m g C \cdot g^{-1}\right)$.

\section{Tableau I}

Les pourcentages de la matière organique totale $(\mathrm{OM})$, de la matière organique labile (LOM) : du ratio de la matière organique totale $(\mathrm{OM})$ au ratio du carbone organique total (COT) et de l'azote total (TN) exprimés en moyennes et écarts-types pour les stations de MOC dans les zones perturbées (D) et non perturbées (UD) et T0, T1, et T2.

\begin{tabular}{|l|c|c|c|c|c|c|}
\hline \multicolumn{7}{|c|}{$\mathrm{D}$} \\
\hline & $\mathrm{T}_{0}$ & $\mathrm{~T}_{1}$ & $\mathrm{~T}_{2}$ & $\mathrm{~T}_{0}$ & $\mathrm{~T}_{1}$ & $\mathrm{~T}_{2}$ \\
\hline OM & $10.56 \pm 1.49$ & $8.65 \pm 1.25$ & $8.89 \pm 1.39$ & $10.78 \pm 1.98$ & $9.31 \pm 1.42$ & $10.11 \pm 1.15$ \\
\hline LOM & $8.38 \pm 1.75$ & $4.73 \pm 0.92$ & $5.86 \pm 1.19$ & $7.62 \pm 2.22$ & $6.21 \pm 0.53$ & $8.66 \pm 1.04$ \\
\hline LOM:OM & $68.59 \pm 18.98$ & $59.64 \pm 10.18$ & $71.24 \pm 12.61$ & $63.58 \pm 14.49$ & $60.43 \pm 9.64$ & $81.8 \pm 9.82$ \\
\hline TOC & $6.33 \pm 0.71$ & & $7.22 \pm 0.83$ & $7.78 \pm 0.66$ & & $9.11 \pm 1.12$ \\
\hline TN & $0.40 \pm 0.17$ & & $0.53 \pm 0.12$ & $0.47 \pm 0.15$ & & $0.81 \pm 0.17$ \\
\hline ChI-a & $4.68 \pm 0.11$ & $10.64 \pm 5.20$ & $4.90 \pm 0.58$ & $2.81 \pm 0.40$ & $4.21 \pm 0.11$ & $4.56 \pm 1.46$ \\
\hline PHAE & $59.92 \pm 12.23$ & $87.74 \pm 10.01$ & $56.38 \pm 8.74$ & $51.53 \pm 25.90$ & $48.43 \pm 5.46$ & $56.80 \pm 14.68$ \\
\hline PRT & $2.18 \pm 1.77$ & $3.58 \pm 0.64$ & $5.00 \pm 1.64$ & $2.80 \pm 1.27$ & $3.91 \pm 0.89$ & $5.10 \pm 1.98$ \\
\hline CHO & $2.91 \pm 1.86$ & $1.83 \pm 0.26$ & $5.21 \pm 2.35$ & $1.50 \pm 0.79$ & $3.13 \pm 0.67$ & $1.78 \pm 1.23$ \\
\hline PRT:CHO & $0.70 \pm 0.13$ & $1.96 \pm 0.24$ & $1.07 \pm 0.45$ & $2.41 \pm 1.82$ & $1.25 \pm 0.12$ & $5.01 \pm 5.50$ \\
\hline LIP & $0.17 \pm 0.03$ & $0.66 \pm 0.22$ & $1.02 \pm 0.35$ & $0.74 \pm 0.29$ & $0.69 \pm 0.25$ & $0.74 \pm 0.43$ \\
\hline BPC & $2.36 \pm 1.59$ & $3.47 \pm 0.88$ & $6.31 \pm 1.32$ & $2.23 \pm 0.85$ & $3.69 \pm 0.84$ & $3.60 \pm 0.41$ \\
\hline C:N & $8.34 \pm 6.37$ & & $7.65 \pm 1.65$ & $7.85 \pm 2.34$ & & $3.90 \pm 0.82$ \\
\hline
\end{tabular}

increased constantly but moderately. PHAE had more or less the same pattern as Chl-a, being more abundant in $\mathrm{D}\left(68.0 \pm 16.4 \mu \mathrm{g} \cdot \mathrm{g}^{-1}\right.$ in $\mathrm{D}$ and $52.2 \pm 14.7 \mu \mathrm{g} \cdot \mathrm{g}^{-1}$ in UD). The PDI, expressed as a percentage of Chl-a with respect to total pigment (T-PIG), was higher in D than UD and, in the first area, the index first increased and then fell sharply, because Chla breaks down readily. $\mathrm{CHO}$ was more abundant in $\mathrm{D}\left(3.3 \pm 2.0 \mathrm{mg} \cdot \mathrm{g}^{-1}\right)$, where it increased greatly in the second half of the study period, than in UD $\left(2.1 \pm 1.0 \mathrm{mg} \cdot \mathrm{g}^{-1}\right)$, where it increased between $T$ and $T_{1}$ and decreased between $T_{1}$ and $T_{2}$. LIP increased in $D$ and did not change in UD. PRT did not show significantly different patterns in D and UD $\left(3.6 \pm 1.6 \mathrm{mg} \cdot \mathrm{g}^{-1}\right.$ and $3.9 \pm 1.5 \mathrm{mg} \cdot \mathrm{g}^{-1}$, respectively). The protein:carbohydrate ratio (PRT:CHO) was substantially constant in D and showed an increase in UD between $T$ and $T_{2}$. BPC was more abundant in $\mathrm{D}\left(4.0 \pm 2.0 \mathrm{mg} \cdot \mathrm{g}^{-1}\right)$, where it showed a constant increase, than in UD $\left(3.2 \pm 0.9 \mathrm{mg} \cdot \mathrm{g}^{-1}\right)$. OM showed similar trends in the two areas but values were on the whole lower in $D(9.8 \pm$ $1.6 \%)$, than in UD $(11.0 \pm 1.0 \%)$. LOM increased more in UD $(6.3 \pm 1.9 \%$ in D and $7.5 \pm$ $1.5 \%$, in UD). LOM predominated over ROM everywhere; indeed, the LOM:OM percentage ratio ranged from $60 \pm 10 \%$ to $82 \pm 10 \%$.

Two-way ANOVA plotted from the database of sediment descriptors showed an absence of any significant difference between $D$ and UD at $T$ for the variables considered (factor accounting for $0.15 \%$ of the total variance; $F=0.45, p=0.507$ ).

Principal components analysis (PCA), plotted on the whole database of variables except atomic TOC and TN, showed that the first three axes explained $78.5 \%$ of the total variance of the system and the first two $62.4 \%$, ensuring high significance of the two-dimensional projection obtained (Figure 3). PRT and BPC were positively related to the $\mathrm{PC}_{1}$ axis, whereas negative relations were recorded for OM and LOM. Chl-a and PHAE were positively related to the $\mathrm{PC}_{2}$ axis, whereas LIP showed a negative relationship. $\mathrm{CHO}$ was not correlated with $\mathrm{PC}_{1}$ or $\mathrm{PC}_{2}$. At T, D and UD stations were close together on the left side of the PCA (Figure 3). On the contrary, at $T_{1}, D$ and UD stations were differentiated by variables correlated with both axes. Specifically, the disturbed area showed an increase in PRT, BPC, Chl-a, and PHAE with 


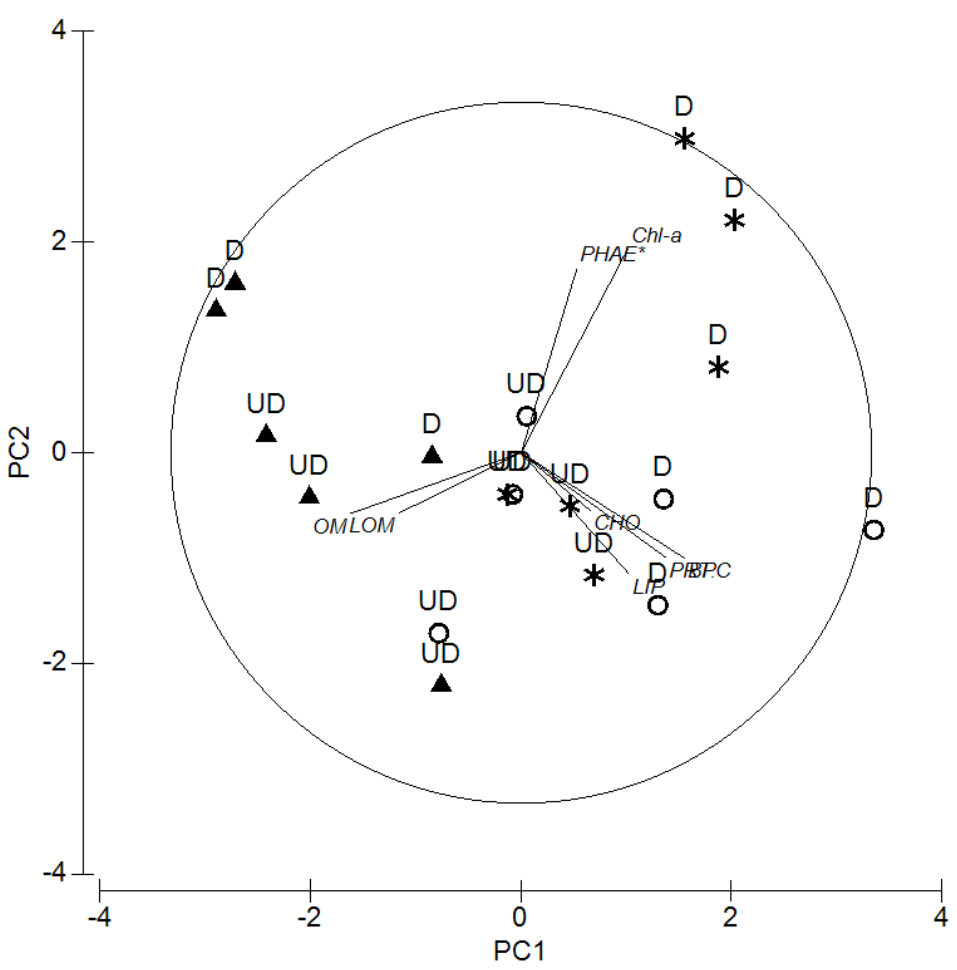

\begin{tabular}{|l|}
\hline disturbance time \\
A T0 \\
* T1 \\
o T2 \\
\hline
\end{tabular}

\begin{tabular}{|c|c|c|}
\hline \multicolumn{3}{|c|}{ Eigenvectors } \\
\hline Variable & PCl & PC2 \\
\hline Chl-a & 0,303 & 0,581 \\
\hline PHAE & 0,158 & 0,524 \\
\hline PRT & 0,414 & $-0,300$ \\
\hline $\mathrm{CHO}$ & 0,197 & $-0,165$ \\
\hline LIP & 0,307 & $-0,346$ \\
\hline BPC & 0,468 & $-0,302$ \\
\hline $\mathrm{OM}$ & $-0,488$ & $-0,174$ \\
\hline LOM & $-0,349$ & $-0,172$ \\
\hline
\end{tabular}

\section{Figure 3}

Two-dimensional principal component analysis (PCA) on the principal chemical components of organic matter. The factors sampling area (disturbed, $D$, and undisturbed, UD) and sampling time $\left(T_{0}, T_{1}, T_{2}\right)$ were considered. Correlation coefficients of the linear combinations of variables of the PCs of the two first axes are also reported. In black, significant positive or negative correlations $(p<0.01)$. Chl-a, chlorophyll-a; PHAE, phaeo-pigments; PRT, proteins; CHO, carbohydrates; LIP, lipids; BPC, biopolymeric carbon; OM, total organic matter; LOM, labile organic matter.

\section{Figure 3}

Analyse des composantes principales (ACP) sur les principaux composants chimiques de la matière organique. Les facteurs surface d'échantillonnage (dérangé, $\mathrm{D}$, et non perturbé, UD) et temps d'échantillonnage (T0, T1, T2) ont été considérés. Les coefficients de corrélation des combinaisons linéaires des variables des deux premiers axes de l'ACP sont également indiqués. En noir, les corrélations positives ou négatives $(p<0,01)$. Chl-a, chlorophylle-a; PHAE, Phéopigments; PRT, protéines; CHO, hydrates de carbone; LIP, lipides, BPC, carbone biopolymères; OM, total des matières organiques; LOM, matière organique labile.

a decrease in LIP, OM and LOM. After seven months of disturbance $\left(T_{2}\right)$, the principal differences between disturbed and undisturbed stations were due to variables correlated with $\mathrm{PC}_{1}$ : an increase in PRT, BPC, LIP and a decrease in OM and LOM in disturbed with respect to undisturbed stations. Differences in disturbed stations at $T_{1}$ and $T_{2}$ were principally due to variables related to $\mathrm{PC}_{2}$ (decrease in Chl-a and PHAE and increase in LIP at $\mathrm{T}_{2}$ ), whereas undisturbed stations showed similar patterns at $T_{1}$ and $T_{2}$.

The distance-based redundancy analysis (dbRDA) performed to associate probabilities with the PCA projection is reported in Figure 4. The percentage of the total variance explained by each axis is also represented, together with factors of interest.

One-way ANOSIM showed a strong influence of disturbance time on the variables (Global $R=0.319$, significance of sample statistic $0.1 \%$, number of permutated statistics greater than or equal to Global $R=12$ ). Two-way ANOVA conducted separately for D and UD (Table II) showed trends significantly affected by disturbance time in $D$, but in UD an interaction effect was not observed (for $D, 4.82 \%$ of total explained variance, $F=13.87, p<0.001$; for UD, $2.0 \%$ of total explained variance, $F=0.15, p=0.080$ ). Two-way ANOSIM, conducted to 


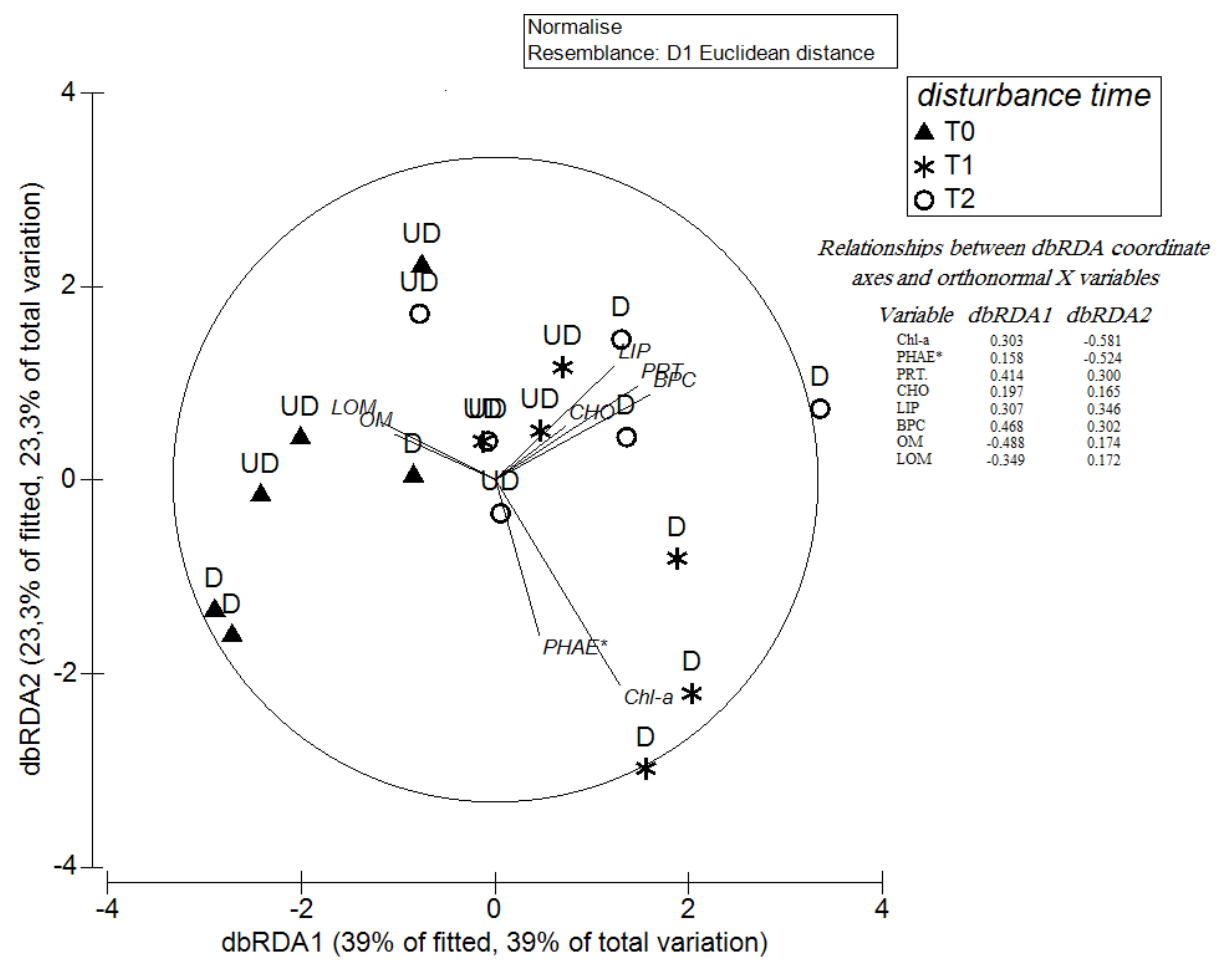

\section{Figure 4}

Distance-based redundancy analysis (dbRDA) of sediment descriptors acquired in the experimental plan of organic matter characterization. The total variation explained by each axis is indicated on the axes; the effect on the total variance due to the factors disturbance $(D, U D)$ and disturbance time $\left(T_{0}, T_{1}, T_{2}\right)$ is also shown.

\section{Figure 4}

Analyse de redondance basée sur les distances (dbRDA) des descripteurs de sédiments acquis dans le plan expérimental de caractérisation de la matière organique. La variation totale expliquée par chaque axe est indiquée sur les axes ainsi que l'effet sur la variance totale due à la perturbation des facteurs (D, UD) et le temps de perturbation (T0, T1, T2).

\section{Table II}

Results of two-way ANOVA for organic matter characterization-experimental plan- stations. $D$, disturbed area; UD, undisturbed area.

\section{Tableau II}

Moyenne et gamme de variation de la matière organique labile (LOM), de la matière organique morte réfractaire $(\mathrm{ROM})$ et du total des matières organiques $(\mathrm{MO})$ dans les stations $F$ et $\mathrm{E}$, pour des fréquences de perturbation appariées.

\begin{tabular}{|l|c|c|c|c|c|c|c|c|c|}
\hline & \multicolumn{3}{|c|}{$\mathrm{D}$} & \multicolumn{5}{c|}{ UD } \\
\hline & Df & Sum-of-squares & Mean square & $F$ & Df & Sum-of-squares Mean square & $F$ \\
\hline Interaction & 14 & 1.70 & 0.12 & 6.10 & 14 & 0.41 & 0.03 & 1.17 \\
\hline Column factor & 2 & 0.53 & 0.27 & 13.28 & 2 & 0.15 & 0.08 & 3.08 \\
\hline Row factor & 7 & 22.67 & 3.24 & 162.20 & 7 & 19.53 & 2.79 & 111.00 \\
\hline Residual & 48 & 0.96 & 0.02 & & 48 & 1.21 & 0.03 & \\
\hline
\end{tabular}

exclude data variability due to the factor disturbance time from variations caused by the factor disturbance, was highly significant (Global $R=0.593$, significance of sample statistic $0.2 \%$, number of permutated statistics greater than or equal to Global $R=2$ ).

Sediment TOC (Table I) did not show significant variations; in fact, two-way ANOVA showed that neither disturbance nor disturbance time were significant factors, accounting for only 


\section{Table III}

Effects of disturbance frequency. Mean \pm standard deviation and range (max-min) of sediment descriptors. The data is grouped according to the factor frequency of disturbance (four levels, fixed: 2, 3, 4, and 5). $L O M=$ labile organic matter (\%), ROM = refractory organic matter (\%), OM = total organic matter (\%).

\section{Tableau III}

Effets de la fréquence des perturbations. Moyenne \pm écart type et gamme (max-min) des descripteurs des sédiments. Les données sont regroupées en fonction de la fréquence des facteurs de perturbation (quatre niveaux, fixes : 2, 3, 4 et 5). LOM = matière organique labile (\%), ROM = matière organique réfractaire $(\%), \mathrm{OM}=$ total de la matière organique.

\begin{tabular}{|l|c|c|c|c|c|c|}
\hline & & \multicolumn{2}{|c|}{ LOM } & \multicolumn{2}{c|}{ ROM } & OM \\
\hline Sub-areas & Frequency & $\mathrm{M} \pm \mathrm{SD}$ & max-min & $\mathrm{M} \pm \mathrm{SD}$ & max-min & $\mathrm{M} \pm \mathrm{SD}$ \\
\hline $\mathbf{B}, \mathbf{I}$ & 2 & $6.85 \pm 1.16$ & $8.93-4.14$ & $3.83 \pm 1.85$ & $7.52-1.56$ & $10.66 \pm 1.04$ \\
\hline $\mathbf{C}, \mathbf{F}$ & 3 & $6.27 \pm 1.98$ & $8.73-2.64$ & $3.50 \pm 0.70$ & $4.89-2.39$ & $9.74 \pm 1.66$ \\
\hline $\mathbf{H}, \mathbf{A}$ & 4 & $5.00 \pm 1.91$ & $8.58-2.65$ & $3.97 \pm 1.38$ & $7.33-1.91$ & $8.97 \pm 1.65$ \\
\hline E, G & 5 & $4.36 \pm 2.45$ & $8.38-2.13$ & $4.28 \pm 1.16$ & $6.00-2.01$ & $8.61 \pm 2.01$ \\
\hline
\end{tabular}

18.31\% $(F=2.34, p=0.177)$ and $<2.22 \%(F=0.28, p=0.61)$ of the total variance, respectively.

Sediment TN (Table I) showed significant differences between disturbed area and undisturbed area at $\mathrm{T}_{2}$; two-way ANOVA showed that the factor disturbance was significant, accounting for $8.91 \%$ of the total variance $(F=7.68, p=0.0126)$, and that disturbance time was an extremely significant factor, accounting for $32.96 \%$ of the total variance $(F=0.28, p=0.61$ ). Stratifying TN data for undisturbed area and disturbed area, the factor disturbance time was significant in UD stations, explaining $22.22 \%$ of the total variance $(F=17.05, p=0.0006)$, but not in D stations, where it only explained $20.96 \%$ of the total variance $(F=1.19, p=0.36)$.

Between $\mathrm{T}$ and $\mathrm{T}_{2}$, the $\mathrm{C}: \mathrm{N}$ ratio declined mainly in undisturbed stations (Table I). Two-way ANOVA showed that disturbance was not a significant factor, accounting for only $0.82 \%$ of the total variance $(F=0.33, p=0.57)$, whereas the factor disturbance time was very significant in undisturbed area, accounting for $59.7 \%$ of the total variance $(F=19.43, p=0.003)$.

The overall macroalgal $\mathrm{C}: \mathrm{N}$ atomic ratio averaged $13 \pm 3$, whereas in disturbed stations and undisturbed stations it averaged $14 \pm 2$ and $12 \pm 4$, respectively. Two-way ANOVA results showed that both disturbance $(9.96 \%$ of total variance; $F=3.36, p=0.14)$ and disturbance time (18.5\% of total variance; $F=1.51, p=0.27)$ and the interaction disturbance vs. disturbance time $(10.7 \%$ of the total variance; $F=0.88, p=0.45)$ were not significant.

\section{> EFFECTS OF INTERVENTION FREQUENCY}

Means $( \pm S D)$ and ranges of LOM, ROM and OM data in intervention frequencyexperimentalplan- stations for subareas disturbed with frequencies of 2, 3, 4 and 5 are shown in Table III. LOM and ROM results are plotted in Figure 5, with LOM on the $x$ axis and ROM on the $y$ axis (regression line: $R O M=-0.35 \pm 0.06 L O M+5.87 \pm 0.37$ ). Each data pair associated with the respective disturbance frequency showed that ROM increased and LOM decreased with increasing frequency. Two-way ANOVA of LOM data (the variable providing the most significant results of the three) showed that both disturbance frequency $(21.70 \%$ of the total variance, $F=37.46, p<0.0001)$ and disturbance time $(35.76 \%$ of the total variance, $F=52.52, p<0.0001$ ) were extremely significant factors.

Two-way ANOSIM, conducted to exclude variability due to the factor disturbance time from variations caused by the factor disturbance frequency, was highly significant (Global $R=$ 0.544 , significance of sample statistic $0.01 \%$, number of permutated statistics greater than or equal to Global $R=0$ ). The pairwise test revealed significant differences between frequencies 2 and 3 (Global $R=0.435$, significance level of sample statistic $0.01 \%$, number of permutated statistics greater than or equal to Global $R=0$ ), with LOM lower at frequency 3 . Higher significance was observed comparing frequencies 2 and 5 (Global $R=0.667$, significance 


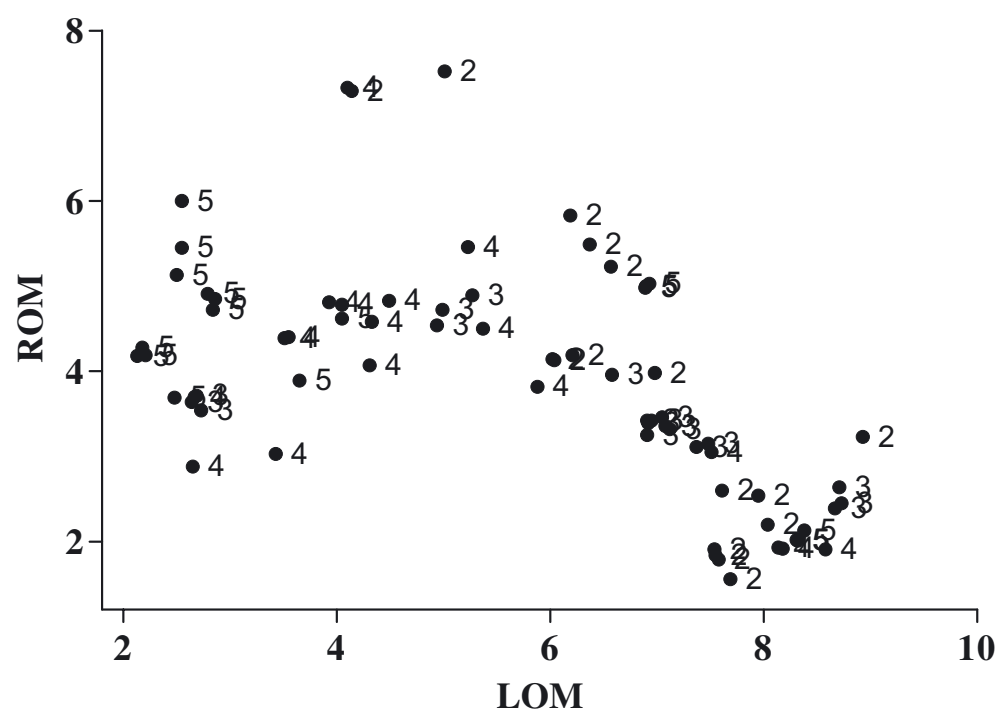

\section{Figure 5}

Linear relationship between LOM ( $x$ axis) and ROM ( $y$ axis) (as percentage dry weight) obtained by the Effect of intervention frequency - experimental plan. The factor frequency (range 2-5) is also shown for each pair of coordinates.

\section{Figure 5}

Relation linéaire entre LOM (axe $x$ ) et ROM (axe y) (en pourcentage de poids sec) obtenu par l'effet de la fréquence d'intervention. La fréquence des facteurs (gamme 2-5) est également indiquée pour chaque paire de coordonnées.

of sample statistic $0.01 \%$, number of permutated statistics greater than or equal to Global $R=0$ ), LOM being lower at the latter frequency (Table III).

\section{DISCUSSION}

\section{> ORGANIC MATTER CHARACTERIZATION - EXPERIMENTAL PLAN}

The disturbed area (D) initially accumulated more organic matter from phytoplankton than the undisturbed area (UD) (Table I, Figure 3). This could have two explanations: (1) resuspension causes nutrient release that initially sustains greater phytoplankton development than in the control area; this causes greater fall-out of phytoplankton that enriches sediment; however, resuspension promotes rapid mineralization, as suggested by the drop in chlorophyll-a (Chl-a) values between the start $\left(T_{1}\right)$ and the end $\left(T_{2}\right)$ of disturbance; (2) resuspended detritus induces flocculation of suspended phytoplankton, which is promptly mineralized in $D$, though phytoplankton may occur anywhere in the lagoon with approximately the same intensity, irrespective of resuspension. The two possibilities may both occur, but the former is not sustained by the results for nutrient release induced by disturbance obtained in previous studies of Lenzi et al. (2005, 2010). Instead, the second possibility is more credible because resuspended detritus can actually form larger flakes with resuspended matter, settling out more readily (Tanaka and Kodama, 2007).

Phaeopigment values were presumably controlled by direct breakdown of macroalgae and phytoplankton, followed by increased mineralization. PDI therefore did not necessarily reflect any decline in photosynthesis in D.

Increases in lipids, proteins and biopolymeric carbon recorded in D (Table I) could similarly be attributed to breakdown of macroalgae, increasing the quantity of cytoplasmic elements available. A large proportion of the biopolymeric carbon consisted of labile matter throughout the lagoon, presumably due to the abundance of macroalgal and also microphyte production. 
Nevertheless, LOM dropped more in D than in UD between T and $\mathrm{T}_{2}$ (Table I, Figure 3), causing a relative accumulation of refractory organic matter, especially structural carbohydrates.

Carbohydrates can be a refractory component of BPC, and it was due to this component that BPC also increased in D and tended to fall in UD at $T_{2}$ (Table I). In line with the above, the $P R T: C H O$ ratio was higher in UD, increasing in the second half of the study period (Table I). PRT is a labile biopolymeric component; a PRT:CHO ratio greater than one indicates that a major fraction of BPC consists of freshly produced labile organic matter (Pusceddu et al., 2000). The PRT:CHO ratio provides information about the trophic state of sediment (Pusceddu et al., 2003) and consequently of the ecosystem. A decrease in this ratio indicates the presence of aged organic detritus (Pusceddu et al., 2000) and may be associated with reduced availability of organic matter for consumers (Pusceddu et al., 2005, 2009). The decrease in this ratio observed in D could therefore mean organic matter of lower quality than in UD, which is a good sign in a eutrophic ecosystem.

Resuspension probably accelerated breakdown of organic detritus and cell lysis, producing an initial increase in the PRT:CHO ratio. Subsequently, however, $\mathrm{CHO}$ became relatively more abundant, indicating accumulation of refractory material. On the contrary, accumulation of recent detritus containing a larger labile fraction was probably generally possible in UD. The fact that this ratio was greater in UD indicates a higher risk of summer dystrophic events.

The fact that LOM was greater than ROM (Table I) can be ascribed to the thickness of sediment sampled $(3 \mathrm{~cm})$ and to the eutrophic nature of this lagoon, in which algal turnover is fast, as is turnover of the complex community associated with algal blooms. Indeed, the first centimeters of sediment contain a high proportion of recent organic detritus that supports biological mineralization and conversion to inorganic components.

The greater increase in $\mathrm{N}$ in sediment from UD than from $\mathrm{D}$ (Table I) was in line with the increase in LOM observed in the same area and can be interpreted as an increase in eutrophication sensu Sampou and Oviatt (1991). Indeed, C:N ratios of less than 10 trigger microbial mineralization (Gray et al., 2002) and the risk that the process may occur anaerobically is common to both areas. However, the C:N ratio halved in UD between $\mathrm{T}$ and $\mathrm{T}_{2}$, which may mean a higher risk of anoxic crises in this area. The C:N ratios in sediment were always much lower than in macroalgae. There was apparently no direct effect of the C: $\mathrm{N}$ ratio in macroalgae on sediment in either area. The ratios were presumably lowered by the remains of microphytes, phytoplankton and zooplankton, as well as by periphyton and microzoobenthos components, all of which showed ratios of 6-7 (Fenchel and Blackburn, 1979, in Gray et al., 2002).

\section{>FREQUENCY EFFECTS - EXPERIMENTAL PLAN}

This experiment revealed that LOM concentrations were inversely proportional to frequency. A disturbance frequency of 5 therefore seemed to best counteract the production of detritus and the increase in labile components of OM in this environment. However, when mitigating eutrophication by means of disturbance, it will be necessary to establish the plateau of the OM abatement curve with respect to frequency of disturbance in order to determine the frequency associated with optimal abatement. This limit is established by the quantity of ROM, which can itself oxidize and mineralize slowly during resuspension in the water column. However, for the purposes of environmental management of eutrophication, it is not important to establish to what extent disturbance of sediment can mineralize OM, but rather how to prevent anoxic conditions. In a eutrophic lagoon, the risk of anoxic crises is proportional to the quantity of recent labile OM from summer decay of the plant biomass produced in winter and spring. This material is readily degraded by microbial anaerobic sulphate reduction.

\section{CONCLUSION}

The following results emerge from the present experiments: (1) a large proportion of the biopolymeric carbon in the lagoon consisted of labile organic matter, due to abundant 
macroalgal and perhaps also microphyte production; (2) as a whole, the disturbed area showed greater abatement of labile organic matter than the undisturbed area, confirming the hypothesis that this occurs as a consequence of resuspension of sediment; (3) in line with this, the disturbed area seemed to acquire a lower protein:carbohydrate ratio than the undisturbed area, which indicates less availability of labile organic matter and therefore lower risk of extended anoxic events; (4) the undisturbed area, where the C:N ratio of sediment was much lower than in the disturbed area at the end of the study period, was therefore at higher risk of anoxic events; (5) sediment and macroalgal $\mathrm{C}: \mathrm{N}$ ratios did not significantly change in response to disturbance; the former was always much lower than the latter, suggesting that microphytes and other organisms contribute to organic matter in sediment; (6) the disturbed area initially accumulated more organic matter from phytoplankton than the undisturbed area, presumably due to resuspended detritus that induces flocculation of suspended phytoplankton; (7) Chl-a, PHAE and the pigment diversity index did not reflect any decline in photosynthesis in the disturbed area; (8) the efficacy of resuspension was directly proportional to the frequency of disturbance, whereas below a frequency of four, the mineralization induced by resuspension did not compensate for the production of detritus in this eutrophic environment. These results, taken together, provide a more complete picture of the effects induced in eutrophic lagoons by disturbance of sediment. They supplement the results of Lenzi et al. (2005, 2010) and support our hypothesis that artificial disturbance can be used to manage these environments and prevent the consequences of eutrophication.

The proposed technique involves only minor investments and has relatively low running costs. Conventional management of eutrophic lagoons often includes harvesting and disposal of macroalgae, pumping in seawater to increase water turnover, excavation of underwater channels and associated maintenance (Lenzi, 2011). Our solution requires a boat equipped with a pair of motors of the type used to aerate aquaculture ponds (Lenzi et al., 2010), and running costs include one employee, petrol and maintenance of the boat and pumps.

Finally, we do not know to what extent artificially induced oxydative mineralization in autumn and winter contributes to the gases released to the atmosphere by the ecosystem, particularly as regards the carbon cycle. In any case, a great quantity of gases is released during the year, largely due to summer anaerobic processes. What changes is probably the quality of these gases: artificially induced oxydative mineralization releases mainly $\mathrm{CO}_{2}, \mathrm{~N}_{2}$ and $\mathrm{N}_{2} \mathrm{O}$, whereas anoxic processes release $\mathrm{CO}_{2}, \mathrm{CH}_{4}, \mathrm{NH}_{3}$ and $\mathrm{H}_{2} \mathrm{~S}$, the last two of which are toxic. Environmental management of eutrophic lagoons aimed at mitigating the effects of eutrophication by the proposed method could perhaps quickly reduce the major accumulation of organic carbon typical of lake, peatland and transition area sediment (Dean and Gorham, 1998, in Gudasz et al., 2010). However, accelerated release of $\mathrm{CO}_{2}$ by resuspension of sediment does not increase this gas in the atmosphere, as in the case of combustion of fossil fuels (the carbon of which was removed from the atmosphere millions of years ago), since the $\mathrm{CO}_{2}$ emitted was obtained from the atmosphere a few months earlier and does not prevent the burial of organic carbon of refractory components. Above all, eutrophic lagoons mainly develop macroalgae and/or microalgae, that produce organic detritus that is very bioavailable. The technique of oxidizing surface sediment (the sediment of one or two years of detritus) favors the predominance of angiosperms (Lenzi et al., 2010), which mainly produce refractory detritus, increasing the fraction of organic matter that will be buried over geological timescales.

\section{ACKNOWLEDGEMENTS}

This research was approved by the Management Committee of Burano Lagoon and financed by the Italian Ministry for the Environment and Land and Sea Protection (MATTM). We thank WWF-Italy at the Nature Reserve of Burano Lake for assistance and logistics and the operational staff in the field (Dr. Rugiada Roffilli, Dr. Francesca Birardi, Dr. Duccio Solari). Some of the analytical determinations were conducted by EcoTechSystems s.r.l. (a spin-off of Università Politecnica delle Marche, Italy). 


\section{REFERENCES}

Arnosti C. and Holmer M., 2003. Carbon cycling in a continental margin sediment: contrasts between organic matter characteristics and reminaralization rates and pathways. Estuar. Coast. Shelf S., 58, 197-208.

Benedetti-Cecchi L., 2004. Experimental design and hypothesis testing in ecology. Biologia Marina Mediterranea, 11, 407-455.

Bligh E.G. and Dyer W., 1959. Rapid method for total lipid extraction and purification. Canadian Journal of Biochemistry and Physiology, 37, 911-917.

Cebrián J., Williams M., McClelland J. and Valiela I., 1998. The dependence of heterotrophic consumption and $\mathrm{C}$ accumulation on autotrophic nutrient concentration in ecosystems. Ecol. Lett., 1, 165170.

Clarke K.R. and Warwick R.M., 2001. Change in marine communities: an approach to statistical analysis and interpretation, 2nd Edition, Primer-E, Plymouth.

Cochran W.G., 1977. Sampling techniques, 3rd Edition, Wiley \& Sons, New York.

Cornwell J.C., Conley D.J., Owens M. and Stevenson J.C., 1996. A sediment chronology of the eutrophication of Chesapeake Bay. Estuaries, 19, 488-499.

Danovaro R., Marrale D., Della Croce N., Parodi P. and Fabiano M., 1999. Biochemical composition of sedimentary organic matter and bacterial distribution in the Aegean Sea: trophic state and pelagicbenthic coupling. J. Sea Res., 42, 117-129.

Dell'Anno A., Mei M.L., Pusceddu A. and Danovaro R., 2002. Assessing the trophic state and eutrophication of coastal marine systems: a new approach based on the biochemical composition of sediment organic matter. Mar. Pollut. Bull., 44, 611-622.

Den Hartog C., 1994. Suffocation of a littoral Zostera bed by Enteromorpha Radiata. Aquat. Bot., 47, 21-28.

Di Nigel T.F., 2002. Methods in agricultural chemical analysis: a practical handbook, CABI, $266 \mathrm{p}$.

Duarte C.M., 1995. Submerged aquatic vegetation in relation to different nutrient regimes. Ophelia, 41, 87-112.

Dubois M., Gilles K., Hamilton J.K., Rebers P.A. and Smith F., 1956. Colorimetric method for determination of sugar and related substances. Anal. Chem., 28, 350-356.

Fabiano M., Danovaro R. and Fraschetti S., 1995. A three-year time series of elemental and biochemical composition of organic matter in subtidal sandy sediments of the Ligurian Sea (northwestern Mediterrenean). Cont. Shelf. Res., 15, 1453-1469.

Farias L., 2003. Remineralization and accumulation of organic carbon and nitrogen in marine sediments of eutrophic bays: the case of bay of concepcion, Chile. Estuar. Coast. Shelf S., 57, 829-841.

Gerchakov S.M. and Hatcher P.G., 1972. Improved technique for analyses of carbohydrates in sediments. Limnol. Oceanogr., 17, 938-943.

Golterman H.L., 2001. Phosphate release from anoxic sediments or "what did Mortimer really write?". Hydrobiologia, 450, 99-106.

Gray J.S., Wu R.S.S. and Or Y.Y., 2002. Effects of hypoxia and organic enrichment on the coastal marine environment. Mar. Ecol. Prog. Ser., 238, 249-279.

Gudasz C., Bastviken D., Steger K., Premke K., Sobek S. and Tranvik L.J., 2010. Temperature-controlled organic carbon mineralization in lake sediments. Nature, 466, 478-481.

Hartree E.F., 1972. Determination of proteins: modification of the Lowry methods that give a linear photometric response. Anal. Biochem., 48, 422-427.

Heijs S.K., Azzoni R., Giordani G., Jonkers H.M., Zizzoli D., Viaroli P. and Gemerden H., 2000. Sulphideinduced release of phosphate from sediments of coastal lagoons and the possible relation to the disappearance of Ruppia sp. Aquat. Microb. Ecol., 23, 85-95.

Hopkinson Jr. C.S., 1985. Shallow-water benthic and pelagic metabolism: evidence of heterotrophy in the near shore Georgia bight. Mar. Biol., 87, 19-32.

Jørgensen B.B., 1983. The microbial sulphur cycle. In: Krumbein W. (ed.), Microbial Geochemistry, Blackwell Scientific Publications, Oxford, 91-124.

Lenzi M., 2010. Resuspension of sediment as a method for managing shallow eutrophic lagoons. Journal of Ecology and the Natural Environment, 2, 220-234. ISSN 2006-9847 (C2010, http:// academicjournals.org/jene.

Lenzi M., 2011. Resuspension of sediment as a possible environmental management method for coastal lagoons and aquaculture ponds. J. Aquac. Res. Development, 2, 104e. doi: 10.4172/21559546.1000104e (http://dx.doi.org/10.4172/2155-9546.1000104e).

Lenzi M., Porrello S. and Palmieri R., 2003. Restoration of the eutrophic Orbetello lagoon (Tyrrhenian Sea, Italy): water quality management. Mar. Pollut. Bull., 46, 1540-1548. 
Lenzi M., Finoia M.G., Persia E., Comandi S., Gargiulo V., Solari D., Gennaro P. and Porrello S., 2005. Biogeochemical effects of disturbance in shallow water sediment by macroalgae harvesting boats. Mar. Pollut. Bull., 50, 512-519.

Lenzi M., Birardi F., Calzolai R., Finoia M.G., Marcone F., Nocciolini S., Roffilli R., Sgroi S. and Solari D., 2010. Hypertrophic lagoon management by sediment disturbance. Mar. Pollut. Bull. (Issue 4-6, Estuarine Ecosystems: Structure, Function and Management - ECSA-42 Symposium in Russia), $61,189-197$.

Logan B.E. and Kirchman D.L., 1991. Uptake of dissolved organics by main bacteria as a function of fluid motion. Mar. Biol., 111, 175-181.

Loh P.S., 2005. An assessment of the contribution of terrestrial organic matter to total organic matter in sediments in Scottish sea lochs, Ph.D. thesis, UHI Millenium Institute, $350 \mathrm{p}$.

Lorentzen C.J. and Jeffrey S.W., 1980. Determination of chlorophyll and phaeopigments spectrophotometric equation. Limnol. Oceanogr., 12, 343-346.

Marsh J.B. and Weinstein D.B., 1966. A simple charring method for determination of lipids. J. Lipid Res., 7, 574-576.

Middelburg J., Nieuwenhuize J. and van Breugel P., 1999. Black carbon in marine sediments. Mar. Chem., 65, 245-252.

Morand P. and Briand X., 1996. Excessive Growth of Macroalgae: A Sympton of Environmental Disturbance. Bot. Mar., 39, 491-516.

Pusceddu A., Dell'Anno A. and Fabiano M., 2000. Organic matter composition in coastal sediments at Terra Nova Bay (Ross Sea) during summer 1995. Pol. Biol., 23, 288-293.

Pusceddu A., Dell'Anno A., Danovaro R., Marini E., Sarà G. and Fabiano M., 2003. Enzymatically hydrolysable protein and carbohydrate sedimentary pools as indicators of the trophic state of "detritus sink" systems: a case study in a Mediterranean coastal lagoon. Estuaries, 26, 641-650.

Pusceddu A., Grémare A., Escoubeyrou K., Amoroux J.M., Fiordelmondo C. and Danovaro R., 2005. Impact of natural (storm) and anthropogenic (trawling) sediment resuspension on particulate organic matter in coastal environments. Cont. Shelf Res., 25, 2506-2520.

Pusceddu A., Dell'Anno A., Fabiano M. and Danovaro R., 2009. Quantity and bioavaillability of sediment organic matte ras signatures of benthic trophic status. Mar. Ecol. Prog. Ser., 375, 41-52.

Raffaelli D.G., Raven J.A. and Poole L.J., 1998. Ecological impact of green macroalgal blooms. Oceanography and Marine Biology: an Annual Review, 36, 97-125.

Sampou P. and Oviatt C.A., 1991. Seasonal patterns of sedimentary carbon and anaerobic respiration along a simulated eutrophication gradient. Mar. Ecol. Prog. Ser., 72, 271-282.

Stahlberg C., Bastviken D., Svensson B.H. and Rahm L., 2006. Mineralisation of organic matter in coastal sediment at different frequency and duration of resuspension. Estuar. Coastal Shelf Sci., 70, 317-325.

Tanaka K. and Kodama M., 2007. Effects of resuspended sediments on the environmental changes in the inner part of Ariake Bay, Japan. Bulletin of Fisheries Research Agency, 19, 9-15.

Tengberg A., Almroth E. and Hall P., 2003. Resuspension and its effects on organic carbon recycling and nutrient exchange in coastal sediments: in situ measurements using new experimental technology. J. Exp. Mar. Biol. Ecol., 285-286, 119-142.

Tenore K.R., Kammen L., Findlay S.E.G. and Phillips N., 1982. Perspective of research on detritus: do factors controlling the availability of detritus to macroconsumers depends on its source? J. Mar. Res., 40, 473-489.

Underwood A.J., 1992. Beyond BACl: The detection of environmental impacts on populations in the real, but variable, world. J. Exp. Mar. Biol. Ecol., 161, 145-178.

Underwood A.J., 1993. The mechanics of spatially replicated sampling programmes to detect environmental impacts in a variable world. Australian Journal of Ecology, 18, 99-116.

Valiela I., MacLelland J., Hauxwell J., Beher P.J., Hersh D. and Foreman K., 1997. Macroalgal blooms in shallow estuaries: controls and ecophysiological and ecosystem consequences. Limnol. Oceanogr., 42, 1105-1118.

Wainright S.C., 1990. Sediment-to-water fluxes of particulta material and microbes by resuspension and their contribution to the planktonic food web. Mar. Ecol. Prog. Ser., 62, 271-281.

Wainright S.C. and Hopkinson Jr. C.S., 1997. Effects of sediment resuspension on organic matter processing in coastal environments: a simulation model. J. Mar. Syst., 11, 353-368.

Wang Q. and Li Y., 2010. Optimizing the weight-loss-on-ignition methodology to quantify organic and carbonate carbon of sediments from diverse sources. Environ. Monitor. Assess., 17, DOI 10.1007/s10661-010-1454-z.

WWF-Italia, 1993. Multidisciplinary study for the protection of the aquatic ecosystem of Burano Lake (GR), WWF-Italy and Italian Ministry of Environment (MATT), $242 \mathrm{p}$. 